\title{
Jaguarundi (Puma yagouaroundi) predation by puma (Puma concolor) in the Brazilian Atlantic Forest
}

\author{
${\text { Marcelo } \text { Magioli }^{I^{*}} \text { \& Katia Maria P. M de Barros Ferraz }}^{1}$ \\ ${ }^{1}$ Universidade de São Paulo, Departamento de Ciências Florestais, Escola Superior de Agricultura \\ “Luiz de Queiroz”, Laboratório de Ecologia, Manejo e Conservação de Fauna (LEMaC), Piracicaba, SP, Brazil \\ *Corresponding author: Marcelo Magioli, e-mail: marcelo.magioli@gmail.com
}

MAGIOLI, M.; FERRAZ, K. M. Jaguarundi (Puma yagouaroundi) predation by puma (Puma concolor) in the Brazilian Atlantic Forest. Biota Neotropica. 18(1): e20170460. http://dx.doi.org/10.1590/1676-0611-BN-2017-0460

\begin{abstract}
The jaguarundi (Puma yagouaroundi) is the second most widespread carnivore of the Americas, and considered a threatened species in Brazil. However, most of its ecology is unknown, and few information is available about species that may act as its predator. In this study we present evidence of the predation of a jaguarundi by puma (Puma concolor) in a protected area (Carlos Botelho State Park) in the state of São Paulo, southeastern Brazil. We collected fecal samples in trails and dirt roads in the study area, and by using hair cuticle imprints and medullar patterns, we identified a puma scat containing hair and claws of a jaguarundi. Pumas usually consume carnivores, but the presence of felids is uncommon, especially in Brazil. This could be considered an antagonist interaction, but pumas and jaguarundis do not compete for territory or prey in large protected areas, since pumas have a high intake of larger prey $(>1 \mathrm{~kg})$. Thus, we conclude that this an episode of intraguild predation for feeding purposes, not a kill in response to competition for prey or territory. This is an important record that helps to understand a bit more of the complex trophic relationships in tropical forests.
\end{abstract}

Keywords: Intraguild predation; Trophic interactions; Diet; Felids; Feces

\section{Predação do gato-mourisco (Puma yagouaroundi) por onça-parda (Puma concolor) na Mata Atlântica}

\begin{abstract}
Resumo: O gato-mourisco (Puma yagouaroundi) é o segundo carnívoro com maior distribuição nas Américas, e considerado vulnerável a extinção no Brasil. No entanto, grande parte de sua ecologia é desconhecida, e há pouca informação disponível sobre espécies que poderiam atuar como seu predador. Nesse estudo, apresentamos evidências da predação do gato-mourisco por onça-parda (Puma concolor) em uma unidade de conservação (Parque Estadual Carlos Botelho) no estado de São Paulo. Coletamos amostras fecais de onça-parda em trilhas e estradas de terra na área estudada, e por meio da análise de microestrutura dos pelos, identificamos pelos e garras de um gato-mourisco em uma das amostras fecais. As onças-pardas normalmente consomem carnívoros, mas a predação de outros felinos é incomum, especialmente no Brasil. Essa poderia ser considerada uma interação antagonista, mas a onça-parda e o gato-mourisco não competem por território ou presas em grandes áreas protegidas, uma vez que as onças-pardas consomem preferencialmente presas maiores $(>1 \mathrm{~kg})$. Portanto, concluímos que esse é um episódio de predação intraguilda com propósito alimentar da onça-parda, e não uma predação por conta de competição por território ou presas. Esse registro é importante e ajuda a compreender um pouco mais sobre as complexas relações tróficas em florestas tropicais.
\end{abstract}

Palavras-chave: Predação intraguilda; Relações tróficas; Dieta; Felídeos; Fezes

\section{Introduction}

The jaguarundi, Puma yagouaroundi (É. Geoffroy Saint-Hilare, 1803), occurs in the Latin America, from the borders of USA/Mexico to Argentina (Caso et al. 2015), but is possibly extinct in the USA. In Brazil, where the species is most widely distributed, it was included in the latest version of the national red list, and now is considered 'vulnerable' to extinction (Portaria 444 2014). Besides to the puma, Puma concolor (Linnaeus, 1771), the jaguarundi is the second most widespread felid of the Americas (Giordano 2016), and probably occurs at low densities (Caso 2013, Caso et al. 2015). It is most diurnal (Caso 2013, Giordano
2016), and can inhabit from more pristine areas - from pine-oak forests to more tropical humid ones - to highly modified landscapes (Giordano 2016, Magioli et al. 2016).

As a generalist mesocarnivore (Oliveira \& Cassaro 1996), the jaguarundi consumes basically small vertebrates such as mammals (rodents and marsupials), its main prey, and significative percentages of birds, reptiles and arthropods (Bianchi et al. 2011, Silva-Pereira et al. 2011, Giordano 2016). Yet, most of the jaguarundi ecology is poorly known (Giordano 2016), and few information is available about species that may act as its predator. Oliveira \& Pereira (2014) present evidence that intraguild and interspecific predation between felids in South America 
is an important interaction for structuring carnivoran communities. Apex predators such as puma and jaguars Panthera onca (Linnaeus, 1758), may have an important impact over mesocarnivore populations, since they consume some of them over time (Crawshaw \& Quigley 2002, Vidolin 2004, Pereira et al. 2010). Thus, information about these interactions is important as supporting evidence.

Here we present evidence of the predation of jaguarundi by puma, in a protected area in the Brazilian Atlantic Forest from fecal samples collection and identification.

\section{Material and Methods}

We carried out our research in Carlos Botelho State Park (PECB; $\left.24^{\circ} 00^{\prime}-24^{\circ} 15^{\prime} \mathrm{S}, 47^{\circ} 45^{\prime}-48^{\circ} 10^{\prime} \mathrm{W}\right)$, a large protected area $(37,000 \mathrm{ha})$ in São Paulo State, Brazil (Figure 1), inserted in the largest forest continuum of the Atlantic Forest ( 1,000,000 ha), between Serra do Mar and Corredor Ecológico de Paranapiacaba. PECB has high richness and diversity of mammal species (Brocardo et al. 2012), being one the most preserved Atlantic Forest remnants, including some threatened species such as Brachyteles arachnoides, Tayassu pecari, Panthera onca and Speothos venaticus, and an important source area of mammals' ecological functions (Magioli et al. 2015).
We collected puma fecal samples in trails and dirt roads in PECB (Figure 1), between October 2014 and July 2016, comprising four sampling campaigns lasting five consecutive days. The samples were stored in plastic bags labeled with data and the trail or dirt road it was collected. The total sampling effort was of $280 \mathrm{~km}$ traversed, and we collected 19 fecal samples characteristics from large felids. We screened the fecal samples adapting the method proposed by Korschgen (1980), which consisted in fragmenting and soaking the feces in water with detergent and alcohol for at least a day, subsequently washing them in running water with a $1 \times 1 \mathrm{~mm}$ mesh sieve. The resulting material was dried in an oven at 50 ${ }^{\circ} \mathrm{C}$, and then screened by separating food items (e.g., hair, bones, claws, feathers), which were placed in plastic bags for later identification of prey and predator guard-hairs.

We identified the species (predator and prey) using cuticle imprints and medullar patterns of the hair samples, adapting the method proposed by Quadros (2002). First, we cleaned the guard-hair with 70\% alcohol and dried it with absorbent paper. Then, we deposited the hair over a slide containing a thin layer of partially dried transparent nail polish and covered it with another slide. The set of slides was pressed in a manual vise and left to rest for $\sim 30 \mathrm{~min}$. Finally, the hair was carefully removed from the slide, and its imprint was observed and photographed under a microscope at $\times 400$ magnification.

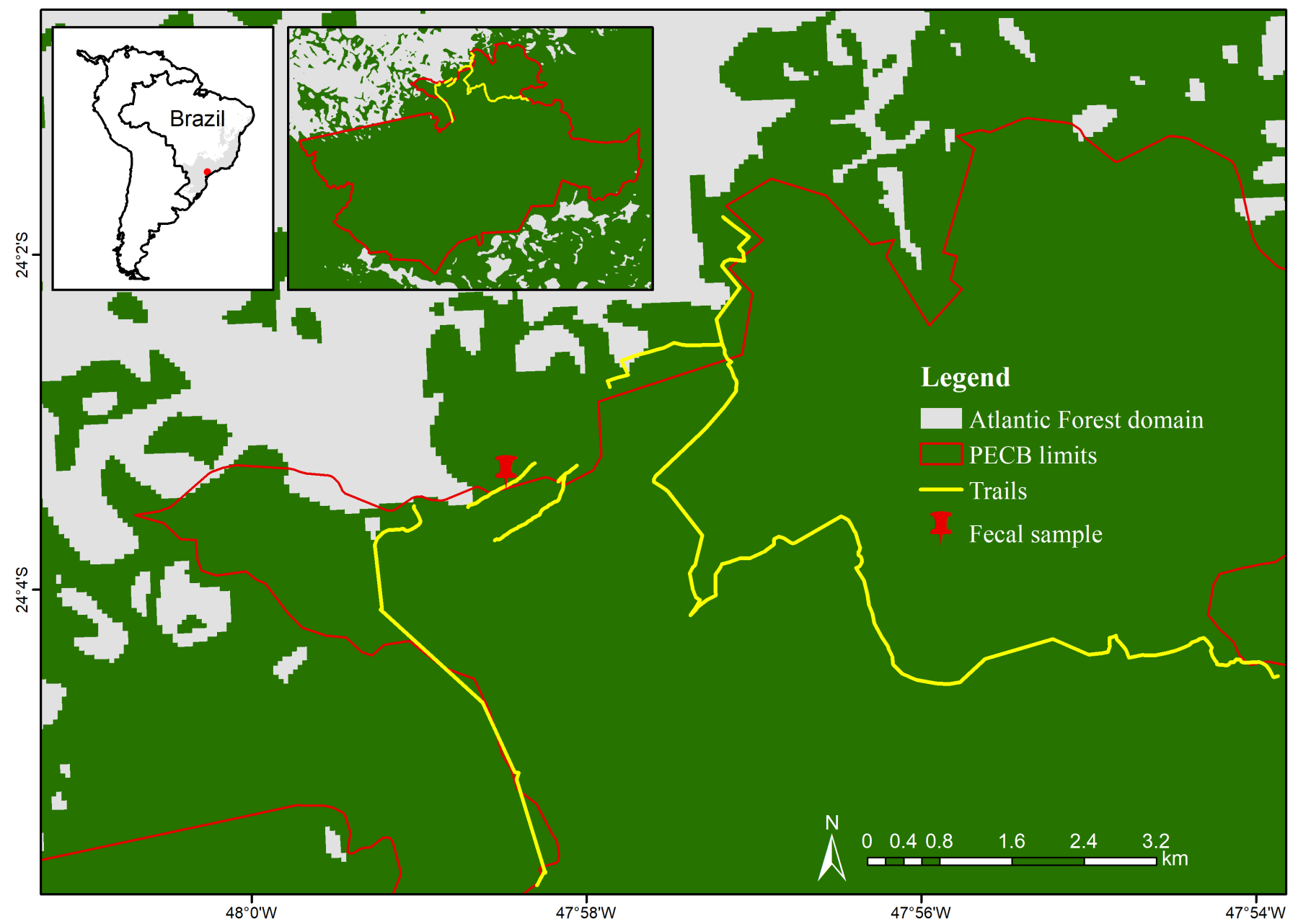

Figure 1. Location of the Carlos Botelho State Park (PECB), São Paulo, Brazil, in the Atlantic Forest biome, highlighting trails and dirt roads used for sampling, and the site where the fecal sample containing evidence of Puma yagouaroundi predation was collected. 
To analyze the medullar patterns, we deposited the guard-hair over a slide containing water and covered it with a cover glass. Then, we observed and photographed the medullar pattern in a microscope at $\times 400$ magnification. To identify the hair cuticle imprints and medullar patterns, we compared our records with photos from Quadros (2002), Miranda et al. (2014) and Amaro (2016). Some samples were previously identified by the presence of tracks close to the feces, or those that were placed at scratches made by pumas.

Fecal samples collection was authorized by IBAMA, through SISBIO permission n. 43680-3, and access to the study area was authorized by COTEC through permission n. $260108-003.547 / 2014$.

\section{Results and Discussion}

From 19 puma fecal samples collected, one presented the jaguarundi as

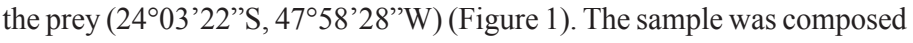
of a huge amount of grey hair, three claws, and few feathers and bones from a bird, a sample very different from any other collected in PECB. Both jaguarundi and puma guard-hairs were identified by cuticle imprints and medullar patterns, besides to the claws of the jaguarundi, which helped to corroborate the identification (Figure 2). We could not tell if the bird items present were eaten by the puma or the jaguarundi.

To our knowledge, the predation of jaguarundis was mentioned in literature only three times. Crawshaw (1995) in Iguaçu National Park, between Brazil and Argentina, and Martins et al. (2008) in Núcleo Juréia-Itatins, an administrative division of the Serra do Mar State Park, São Paulo, Brazil, reported the predation of jaguarundis by pumas. These areas are within the Atlantic Forest, but the area studied by Martins et al. (2008) is closer to PECB ( $\sim 39 \mathrm{~km}$ in a straight line), located also in the forest continuum of Serra do Mar and Corredor Ecológico de Paranapiacaba. In Central Mexico, close to the extreme part of jaguarundi current distribution, MonroyVilchis et al. (2011) reported the predation of an adult male individual by a boa snake, Boa constrictor Linnaeus, 1758 (Squamata, Boidae), but the snake was killed by people before eating the whole individual.

Carnivores are a common prey for big cats such as the puma. In South America, there are several records of carnivore species that had been consumed by pumas (Oliveira \& Pereira 2014). However, the predation of wild cats is uncommon, especially in Brazil. In the south portion of the

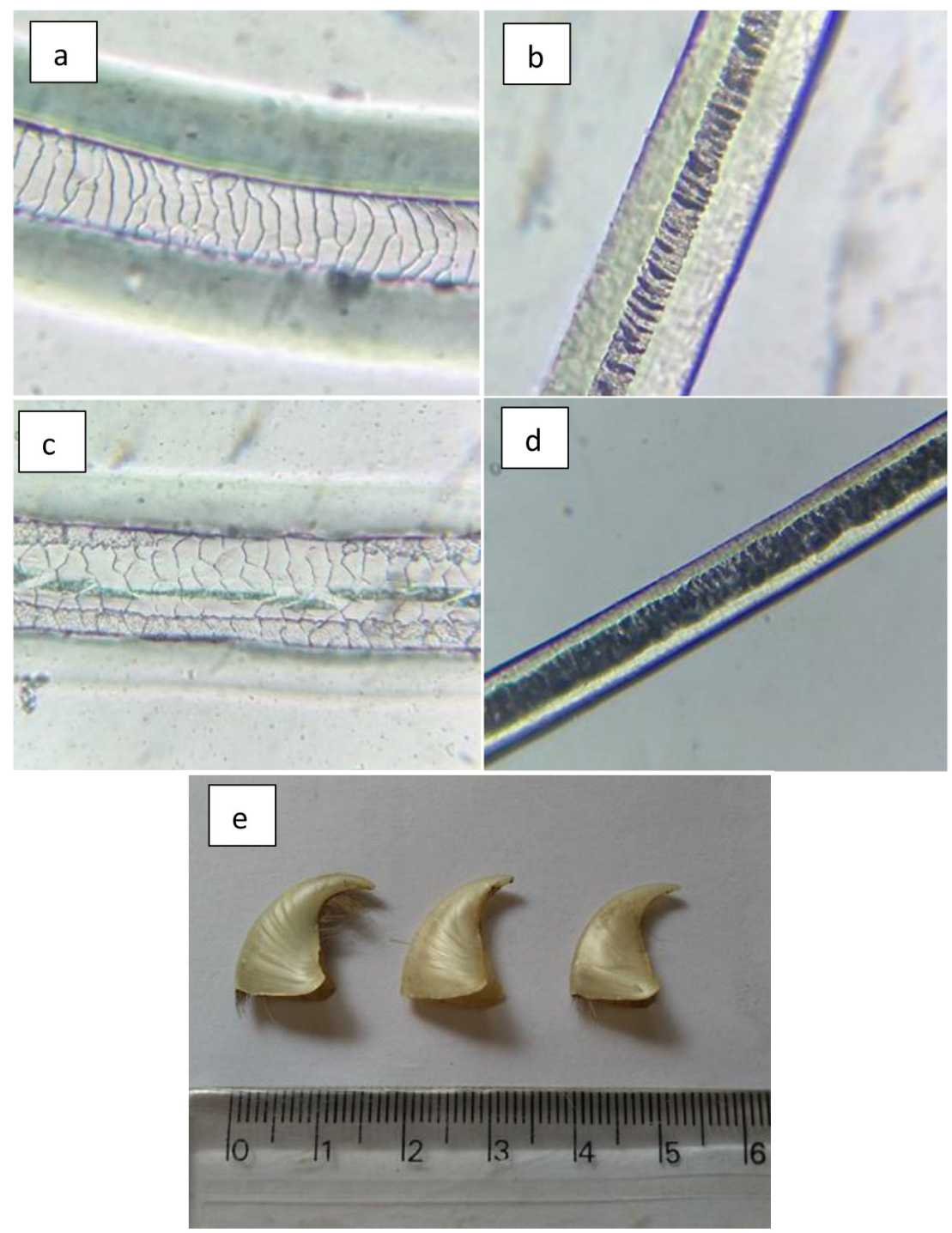

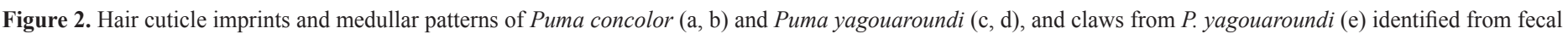
samples in Carlos Botelho State Park (PECB), São Paulo, Brazil, an Atlantic Forest remnant. 
Brazilian Atlantic Forest, Vidolin (2004) recorded the presence of Leopardus pardalis in two puma feces at the Reserva Natural Salto Morato, state of Paraná. In other countries of South America, it has been cited some other felids such as Leopardus sp., Leopardus geofroyi and Leopardus colocolo as part of puma's diet (Oliveira \& Pereira 2014). On the other hand, the predation of bobcats Lynx rufus by pumas in the USA, seems to be a common record, since these species have a great niche overlap (Haas 2009).

The jaguarundi predation could be considered an antagonist interaction - competition for prey and/or territory. However, in large preserved areas of the Atlantic Forest, the feeding habits of pumas and jaguarundis are very different. Pumas feed mainly on medium- and large-sized prey $(>1 \mathrm{~kg})$ (Brito 2000, Azevedo 2008, Martins et al. 2008), while jaguarundis consumes preferentially small vertebrates $(<1 \mathrm{~kg})$ (Bianchi et al. 2011, Silva-Pereira et al. 2011). In modified areas, this antagonist interaction could have a higher possibility of happening, since pumas include a large percentage of small vertebrates in their diet (Rocha et al. 2010, Magioli et al. 2014). Then, it will be more reasonable to think that the pumas would be competing with other small felids for territory and/or prey.

Thus, we conclude that this is an episode of intraguild predation for feeding purposes, not a kill in response to competition for prey or territory. PECB has a high diversity of mammals, presenting several species that are included in pumas' diet, especially the medium- and large-sized mammals. Despite that, pumas are very plastic regarding their habitat use (Magioli et al. 2014) and considered generalist predators, which puts the jaguarundi as an occasional prey. This is an important record that helps to understand a bit more of the complex trophic relationships in tropical forests.

\section{Acknowledgements}

We thank the Forest Science Department (Escola Superior de Agricultura "Luiz de Queiroz", Universidade de São Paulo), the interdisciplinary program in Applied Ecology (PPGI-EA) and the Wildlife Ecology, Management and Conservation Lab (LEMaC). We thank the Fundação Grupo Boticário de Proteção à Natureza for the financial support (Project \#201410014). We thank the Coordenação de Aperfeiçoamento de Pessoal de Nível Superior (CAPES) for the scholarship granted to MM. We thank the São Paulo Research Foundation (FAPESP) for the scholarship granted to MM (grant \#2014/10192-7) and for the grant to KMPMBF (grant \#2014/09300-0). We are indebted to Conselho Nacional de Pesquisa e Desenvolvimento Científico e Tecnológico $(\mathrm{CNPq})$ for the productivity fellowship to KMPMBF (grant \#308503/2014-7).

\section{Author contributions}

Marcelo Magioli: collected and analyzed the data, and wrote the manuscript. Katia Maria Paschoaletto Micchi de Barros Ferraz: wrote the manuscript.

\section{Conflicts of interest}

The authors declare that they have no conflict of interest related to the publication of this manuscript.

\section{References}

AMARO, S. 2016. Guia ilustrado para identificação de mamíferos brasileiros de médio e grande porte a partir da microestrutura de pelos. Monografia, Universidade Vilha Velha, Espírito Santo.

AZEVEDO, F.C.C. 2008. Food habits and livestock depredation of sympatric jaguars and pumas in the Iguacu National Park area, south Brazil. Biotropica 40(4): 494-500.
BIANCHI, R.D.C., ROSA, A.F., GATTI, A. \& MENDES, S.L. 2011. Diet of margay, Leopardus wiedii, and jaguarundi, Puma yagouaroundi, (Carnivora: Felidae) in Atlantic rainforest, Brazil. Zoologia 28(1): 127-132.

BRITO, B.F.A. 2000. Ecologia alimentar da onça parda Puma concolor na Mata Attântica de Linhares, Espírito Santo, Brasil. Dissertação de mestrado, Universidade de Brasília, Brasília.

BROCARDO, C.R., RODARTE, R., BUENO, R.S., CULOT, L. \& GALETTI, M. 2012. Mamíferos não voadores do Parque Estadual Carlos Botelho, continuum florestal do Paranapiacaba. Biota Neotrop. 12(4): 198-208 http:// www.biotaneotropica.org.br/v12n4/en/abstract?inventory+bn02512042012 (last access on 06/10/2017).

CASO, A. 2013. Spatial differences and local avoidance of ocelot (Leopardus pardalis) and jaguarundi (Puma yagouaroundi) in northeast Mexico. $\mathrm{PhD}$ thesis. Texas A\&M University, Kingsville, Texas.

CASO, A., OLIVEIRA, T. \& CARVAJAL, S.V. 2015. Herpailurus yagouaroundi. The IUCN Red List of Threatened Species 2015: e.T9948A50653167. http:/ dx.doi.org/10.2305/IUCN.UK.2015-2.RLTS.T9948A50653167.en. (last access on $06 / 10 / 2017)$.

CRAWSHAW JR., P.G. \& QUIGLEY, H.B. 2002. Hábitos alimentarios del jaguar y el puma en el Pantanal, Brasil, con implicaciones para su manejo y conservación. In El jaguar en el nuevo milenio (R.A. Medellín, C. Equihua, C.L.B. Chetkiewicz, P.G. Crawshaw Jr., A. Rabinowitz, K.H. Redford, J.G. Robinson, E.W. Sanderson \& A.B. Taber, eds). Universidad Nacional Autónoma de México, Wildlife Conservation Society y Fondo de Cultura Económica, México, DF, p. 223-235.

CRAWSHAW JR., P.G. 1995. Comparative ecology of ocelot Felis pardalis and jaguar Panthera onca in a protected subtropical forest in Brazil and Argentina. PhD Dissertation, University of Florida, Gainesville.

GIORDANO, A.J. 2016. Ecology and status of the jaguarundi Puma yagouaroundi: a synthesis of existing knowledge. Mammal Rev. 46(1): 30-43.

HASS, C.C. 2009. Competition and coexistence in sympatric bobcats and pumas. J. Zool. 278(3): 174-180.

KORSCHGEN, L.J. 1980. Procedures for food-habits analyses. In Wildlife management techniques manual (S.D. Schamnitz, ed). The Wildlife Society, Washington, p. 113-127.

MAGIOLI, M., FERRAZ, K.M.P.M.B., SETZ, E.F., PERCEQUILLO, A.R., RONDON, M.V.S.S., KUHNEN, V.V., CANHOTO, M.C.S., SANTOS, K.E.A., KANDA, C.Z., FREGONEZI, G.L., PRADO, H.A., FERREIRA, M.K., RIBEIRO, M.C., VILLELA, P.M.S., COUTINHO, L.L. \& RODRIGUES, M.G. 2016. Connectivity maintain mammal assemblages functional diversity within agricultural \& fragmented landscapes. Eur. J. Wildlife Res. 62(4): 431-446.

MAGIOLI, M., MOREIRA, M.Z., FERRAZ, K.M.P.M.B., MIOTTO, R.A., CAMARGO, P.B., RODRIGUES, M.G., CANHOTO, M.C.S. \& SETZ, E.Z.F. 2014b. Stable isotope evidence of Puma concolor (Felidae) feeding patterns in agricultural landscapes in southeastern Brazil. Biotropica 46(4): 451-460.

MAGIOLI, M., RIBEIRO, M.C., FERRAZ, K.M.P.M.B., \& RODRIGUES, M.G 2015. Thresholds in the relationship between functional diversity \& patch size for mammals in the Brazilian Atlantic Forest. Animal Conservation 18(6): 499-511.

MARTINS, R., QUADROS, J. \& MAZZOLLI, M. 2008. Food habits and anthropic interference on the territorial marking activity of Puma concolor and Leopardus pardalis (Carnivora: Felidae) and other carnivores in the Jureia-Itatins Ecological Station, São Paulo, Brazil. Rev. Bras. Zool. 25(3): 427-435.

MONROY-VILCHIS, O., SÁNCHEZ, Ó. \& URIOS, V. 2011. Consumption of an adult Puma yagouaroundi (Felidae) by the snake Boa constrictor (Boidae) in Central Mexico. Rev. Mex. Biodivers. 82(1): 319-321.

OLIVEIRA, T.G. \& PEREIRA, J.A. 2014. Intraguild predation and interspecific killing as structuring forces of carnivoran communities in South America. J. Mammal. Evol. 21(4): 427-436.

OLIVEIRA, T.G. \& CASSARO, K. 2006. Guia de campo dos felinos do Brasil. Instituto Pró-Carnívoros; Fundação do Parque Zoológico de São Paulo, Sociedade de Zoológicos do Brasil, Pró-Vida Brasil, São Paulo.

PEREIRA, J.A., FRACASSI, N.G., RAGO, V., FERREYRA, H., MARULL, C.A., MCALOOSE, D. \& UHART, M.M. 2010. Causes of mortality in a Geoffroy's cat population - a long-term survey using diverse recording methods. Eur. J. Wildl. Res. 56(6): 939-942 
PORTARIA MMA N. 444. 2014. Reconhece como espécies da fauna brasileira ameaçadas de extinção aquelas constantes da "Lista Nacional Oficial de Espécies da Fauna Ameaçadas de Extinção", trata de mamíferos, aves, répteis, anfíbios e invertebrados terrestres e indica o grau de risco de extinção de cada espécie. http://www.icmbio.gov.br/portal/images/stories/biodiversidade/fauna-brasileira/ avaliacao-do-risco/PORTARIA_N\%C2\%BA_444_DE_17_DE_DEZEMBRO DE_2014.pdf. (last access on 08 October 2015).

QUADROS, J. 2002. Identificação microscópica de pelos de mamíferos e sua aplicação no estudo da dieta de carnívoros. Tese de doutorado, Universidade Federal do Paraná, Curitiba.

ROCHA-MENDES, F., MIKICH, S.B., QUADROS, J. \& PEDRO, W.A. 2010. Feeding ecology of carnivores (Mammalia, Carnivora) in Atlantic forest remnants, southern Brazil. Biota Neotropica 10(4): 21-30 http://www.biotaneotropica.org. br/v10n4/pt/abstract?article+bn00210042010 (último acesso em 06/10/2017).
SILVA-PEREIRA, J.E., MORO-RIOS, R.F., BILSKI, D.R. \& PASSOS, F.C. 2011. Diets of three sympatric Neotropical small cats: Food niche overlap and interspecies differences in prey consumption. Mammal. Biol. 76(3): 308-312.

VIDOLIN, G.P. 2004. Aspectos bio-ecológicos de Puma concolor (Linnaeus, 1771), Leopardus pardalis (Linnaeus, 1758) e Leopardus tigrinus (Schreber, 1775) na reserva natural Salto Morato, Guaraqueçaba, Paraná, Brasil. Dissertação de mestrado, Universidade Federal do Paraná, Curitiba.

Received: 10/10/2017

Accepted: 10/12/2017

Published online: 11/01/2018 